\title{
Kinerja Alat Kondensasi Uap Air Laut Untuk Mendapatkan Air Murni
}

\section{Performance of Seawater Steam Condenser to Gain Pure Water}

\author{
Tamrin $^{1 凶}$ Rivaldo $^{1}$, Warji ${ }^{1}$ \\ ${ }^{1}$ Jurusan Teknik Pertanian Fakultas Pertanian Universitas Lampung \\ ${ }^{\square}$ Komunikasi Penulis, email: tamrinajis62@gmail.com \\ DOI:http://dx.doi.org/10.23960/jtep-l.v10i4.425-431 \\ Naskah ini diterima pada 25 Juni 2020; revisi pada 6 September 2021; \\ disetujui untuk dipublikasikan pada 8 September 2021
}

\begin{abstract}
Testing of a greenhouse model condensation machine to purify the sea water needs to be developed to obtain fresh water. The purpose of this research is to transform seawater using solar energy by using the greenhouse effect principle This research uses testing machine performance to get pure water potential from sea water deselination. The test result of this machine has been able to vaporize seawater in one day ranging from $421 \mathrm{ml}$ $814 \mathrm{ml}$, while water that can be harvested in one day ranges from $97.5 \mathrm{ml}-152.5 \mathrm{ml}$ The energy efficiency gained in this machine ranged from $21.22 \%-46.63 \%$, while the efficiency of the evaporation result of this machine obtained the value ranged from $18.73 \%-24.85 \%$. This machine has been able to convert seawater into fresh water by using the principle of greenhouse effect but still not able to work optimally.
\end{abstract}

Keywords: fresh water, greenhouse effects, seawater

ABSTRAK

Pengujian alat kondensasi model rumah kaca untuk memurnikan air laut perlu dikembangkan untuk mendapatkan air tawar. Tujuan penelitian ini untuk menguji alat kondensasi ai laut untuk mendapatkan potensi air murni dari desalinasi air laut. Hasil pengujian alat ini telah dapat menguapkan air laut dalam satu hari berkisar antara 421$814 \mathrm{ml}$, sedangkan air yang dapat dipanen dalam satu hari berkisar 97,5-152,5 ml. Efisiensi energi yang diperoleh pada alat ini berkisar antara $21,22 \%-46,63 \%$, sedangkan efisiensi hasil penguapan alat ini diperoleh nilai berkisar $18,73 \%-24,85 \%$. Alat ini telah dapat mengubah air laut menjadi air tawar dengan menggunakan prinsip efek rumah kaca namun masih belum mampu bekerja dengan optimal.

Kata kunci : air laut, air tawar, efek rumah kaca

\section{PENDAHULUAN}

Ada beberapa daerah di Indonesia mengalami kekeringan pada musin kemarau dan kesulitan untuk mendapatkan air minum atau air bersih. Daerah yang kesulitan untuk memdapatkan air bersih pada musim kemarau adalah masyarakat yang tinggal di pulau-pulau kecil di Indonesia dan bebera daerah pulau besar seperti 7 dusun di Desa Pucung bagian utara. Desa tersebut dihuni oleh lebih dari 2.000 jiwa.Pada musim kemarau selalu mengalami kekurangan air bersih untuk keperluan sehari- hari. Pada musim kemarau mereka mendapat air dengan cara membeli air dengan harga tinggi dari penjual air yang datang menggunakan truk tangki air (Priyono et al., 2016).
Untuk mendapatkan air murni masyarakat dapat melakukan penyulingan air sungai yang kotor atau air laut yang tinggal di pinggir pantai. Potensi air sungai dan air laut yang melimpah dapat dibuatnya suatu sistem pemurnian air laut menjadi air tawar dengan desain yang mudah dengan bantuan sinar matahari. Menurut Deng et. al. (2010), bahwa peristiwa memurnikan air laut asin menjadi air tawar dinamakan deselinasi.Proses deselinasi air laut menjadi air tawar tersebut akan menjadi biaya rendah apabila menggunakan radiasi matahari sebagai sumber energi. Sedangkan menurut Yuan et. al. (2011) bahwa sumber air dialam dengan jumlahyang banyak terdapat di lautan, namun kualitasnya sangat buruk karena mengandung kadar garam yang cukup tinggi. 
Indonesia terletak didaerah khatulistiwa. Sinar matahari ada sepanjang tahun dan dapat digunakan untuk proses deselinasi untuk menghemat biaya produksi air murni. Disamping itu, Intensitas matahari di Indonesia sebagai sumber panas untuk evaporasi air laut yaitu ratarata $4,8 \mathrm{kWh} /\left(\mathrm{m}^{2}\right.$.hari) (Astawa, 2008). Proses desalinasi jelas memerlukan energi untuk menguapkan air laut Pengunaan energy matahari merupakan biaya yang murah bila dibandingkan dengan menggunakan eenergi fosil (Yilmaz dan Soylemez, 2012).

Menurut Lanto dan Iswadi (2016) prinsip kerja untuk mendapatkan air murni dari air laut adalah dengan menguapkan air laut didalam suatu ruang yang dindingnya terbuat dari kaca yang dirancang berbentuk peramida. Energi matahari yang masuk keruangan melalui efek rumah kaca akan meningkatkan suhu didalam ruang dan memanaskan air laut dan menguapkannya. Air yang menguap dan menempel pada dinding kaca bagian dalam.Kumpulan uap yang menempel dipermukaan kaca akan mengalir dipermukaan kaca ke bawah dan air tesebut ditampung dibawah.

Zulkarnain et al. (2018) mengujialat pemurni air laut tenaga surya dengan kolektor panas cermin cekung sebagai sumber panas dan air laut didalam kotak destilasi sederhana berbahan dasar kayu yang dipanaskan langsung sinar matahari, mampu menghasilkan air tawar maksimal $1718 \mathrm{ml}$ air, suhu pada bagian evaporator mencapai $79{ }^{\circ} \mathrm{C}$ dengan lama pemanasan 10 jam. Sedangkan Effendi et al. (2012) menguji alat pemurnian air laut berbentuk kotak dengan pemanasan awal (preheater) mendapatkan hasil air murni 380,3 $\mathrm{ml}$ selama 6 jam.

Dalam usaha untuk mendapatkan air murni dari evaporasi air laut dalam proses deselinasi, maka diadakan peneltian dengan tujuan untuk mendapatkan potensi air murni yang akan diporoleh selama penguapan air laut didalam ruang dengan pemanasan mengunakan prinsip efek rumah kaca. Penelitian dilakukan diruang terbuka, sehingga sinar matahari tidak terhalang untuk memanasi ruang evaporasi air laut.

\section{BAHAN DAN METODE}

\subsection{Kriteria Desain}

Alat kondensasi model rumah kaca ini dirancang bangun guna memenuhi kriteria desain yakni alat minimal telah mampu bekerja dengan prinsip kerja proses penyulingan dan kemampuan untuk melakukan proses penyulingan tersebut dilakukan selama 10 jam per hari. Pelaksanaan penyulingan ini dilakukan pada bulan November 2019 sampai dengan Januari 2020 di Laboratorium Lapang Terpadu, Fakultas Pertanian, Universitas Lampung.

\subsection{Tahap Pembuatan Alat}

Alat kondensasi model rumah kaca terdiri dari beberapa proses yaitu pembuatan desain alat, pemilihan alat dan bahan, pembuatan kerangka alat, pembuatan bak penampung air laut, pemasangan komponen seperti bak penampung air laut ke dalam alat, pemasangan dinding plastik, tahap pengujian alat, serta pengamatan dan analisis data.

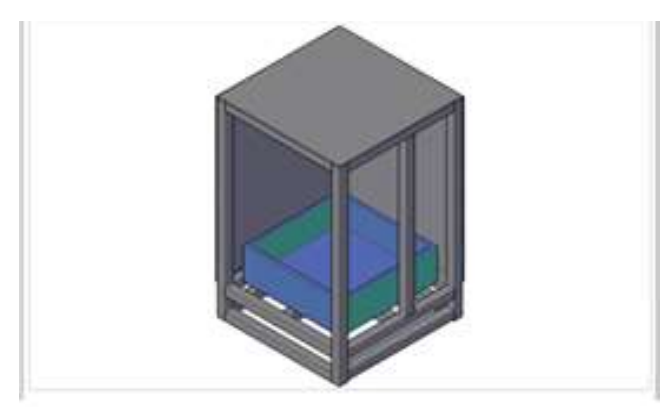

Gambar 1. Alat Kondensasi Uap Air Laut 


\subsection{Komponen Alat}

Bagian-bagian yang terdapat pada alat kondensasi model rumah kaca ini yaitu rangka utama, bak penampung air laut, plastik transparan.

1. Rangka utama memiliki panjang $125 \mathrm{~cm}$, lebar $80 \mathrm{~cm}$, dan tinggi $80 \mathrm{~cm}$. Bahan pembuatan kerangka yaitu kayu kaso dengan ketebalan $5 \times 5 \mathrm{~cm}$ berbentuk persegi.

2. Bak penampung air laut berbentuk persegi panjang dengan dimensi panjang $75 \mathrm{~cm}$, lebar $75 \mathrm{~cm}$, dan tinggi $20 \mathrm{~cm}$. Bak penampung air laut ini dapat menampung air laut berjumlah 102 liter.

3. Plastik transparan yang digunakan dalam pada alat ini memiliki ketebalan $0.23 \mathrm{~mm}$ untuk membalut ruang evaporasi dalam bentuk 4 sisi.

\subsection{Mekanisme Kerja Alat}

Alat pemurnian air laut dalam bentuk kubus yang dindingnya ditutup dengan plastik. Air laut didalam wadah dimasukan kedalam kubus atau kotak.Radiasi cahaya matahari pada kondisi gelombang pendek masuk kedalam kotak melewat dinding plastik. Radiasi cahaya matahari diukur dengan menggunakan lux meter. Nilai radiasi dengan lux meter dikonversi menjadi 0,01 $\mathrm{W} / \mathrm{m}^{2}$. Didalam kotak radiasi matahari berubah menjadi gelombang panjang dan terperangkap didalam kotak, sehingga radiasi matahari berubah menjadi panas. Energi panas ini akan menguapkan air laut. Uap air laut sebagian mengembun pada dinding plastik dan sebagian keluar dari melalui celah yang ada pada didinding kotak. Air yang mengembun pada dinding plastik dipanen dengan mengusap dinding plastik dengan wiper. Uap air yang mengembun pada plastik tidak dibiarkan sampai jatuh sendiri ke bawah, tapi langsung dipanen, jika sudah memungkinkan untuk dipanen. Hal ini karena dikuatirkan butiran air terlalu lama dipermukaan plastik, sehingga sebagian butiran air menguap lagi karena panasnya suhu didalam kotak dan dinding plastik tidak benar-benar kedap. Air yang dipanen ditampung didalam wadah dari belahan pralon selebar dinding plastik. Kemudian air yang dipanen tersebut dikumpulkan dan dimasukkan kedalam botol plastik transparan. Volume air yang didapat diukur dengan menggunakan gelas ukur.

\section{HASIL DAN PEMBAHASAN}

\subsection{Hasil Penelitian}

Alat kondensasi model rumah kaca dapat mengubah air laut menjadi air tawar dengan menggunakan prinsip efek rumah kaca. Alat ini dibuat berdasarkan penjelasan pendahuluan yang telah dijelaskan. Alat kondensasi dapat dilihat pada Gambar 2.

1. Rangka utama alat kondensasi model rumah kaca ini berfungsi untuk menjadi pengampu bagian-bagian alat lainnya. Seperti bak penampung air laut dan plastik transparan pada dinding alat.

2. Bak penampung air laut berfungsi untuk menampung air laut di dalam alat yang akan diuapkan. Bak ini dilapisi oleh plastik dengan ukuran sesuai bak agar mengurangi terjadinya kebocoran pada bak.

3. Kegunaan dari plastik transparan pada alat 2 ini untuk menutupi alat secara rapat atau vacum. Ketika proses penguapan terjadi plastik akan menyerap sinar matahari yang melewati plastik, sehingga sinar atau gelombang panas matahari dapat terperangkap di dalam alat yang membuat keadaan didalam alat menjadi panas.

\subsection{Hasil Uji Kinerja}

Pengujian alat dilakukan dalam 3 kali percobaan. Parameter dalam percobaan yaitu suhu dan radiasi matahari. Hasil uji kinerja yang diperoleh dinyatakan dalam diagram batang. Grafik hasil uji kinerja alat menunjukkan bahwa, penyulingan air laut dipengaruhi oleh radiasi matahari serta suhu di dalam alat. Pada dasarnya, Alat ini mengacu pada prinsip efek rumah kaca, sinar matahari yang berupa gelombang pendek dan masuk ke dalam alat berubah menjadi gelombang panjang membuat sinar matahari terperangkap di dalam ruang penguapan yang menyebabkan suhu di ruang penguapan menjadi naik sehingga timbul energi yang dapat membuat air laut menguap. Namun pemanenan dilakukan dengan melihat kondisi embun atau tetesan air yang menempel pada dinding plastik telah memungkinkan untuk di panen. Apabila telah mengalami pembentukan menjadi embun maka pemanenan dilakukan. Namun, jika tidak dalam kondisi yang memungkinkan untuk dipanen 


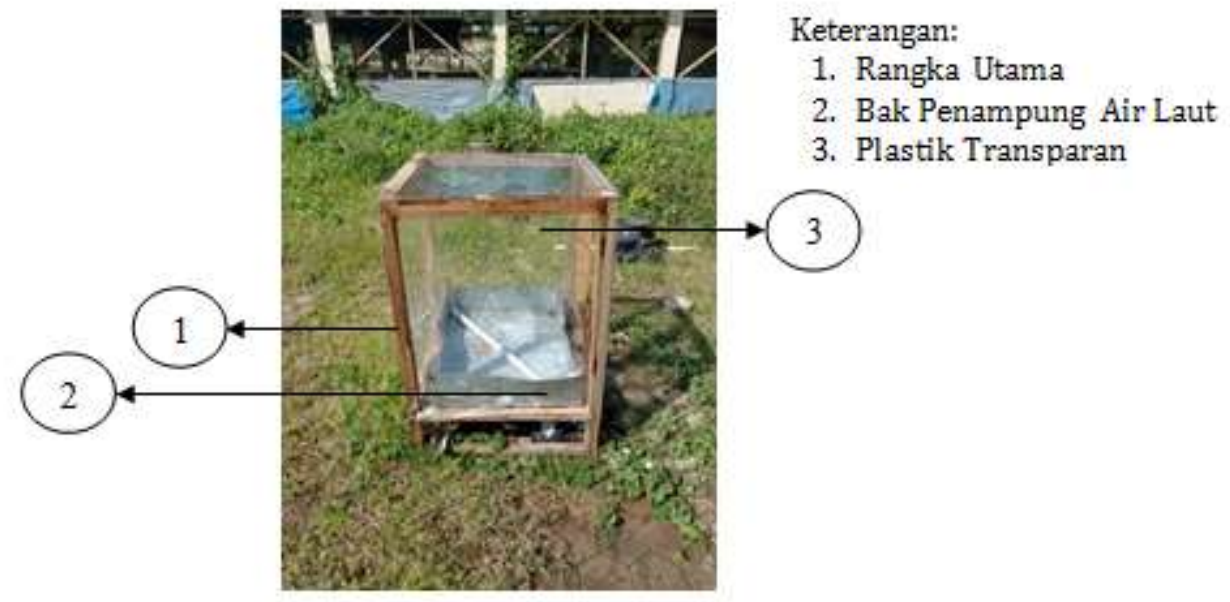

Gambar 2. Alat Kondensasi Uap Air Laut Model Rumah Kaca

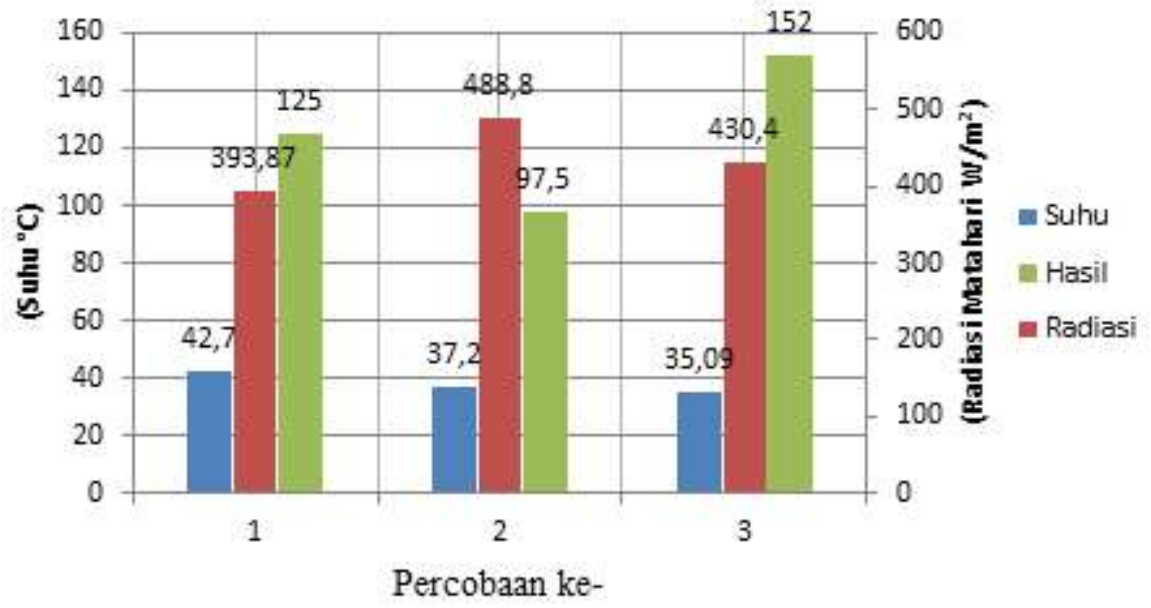

Gambar 3. Hasil Uji Kinerja Alat Kondensasi Uap Air Laut

maka pemanenan tidak dilakukan dikarenakan akan menimbulkan kehilangan air atau lose.

\subsection{Rata-rata Suhu dan Radiasi Matahari}

Pengujian alat kondensasi model rumah kaca ini dilakukan selama tiga kali berturut-turut. Parameter yang diukur yaitu suhu dan radiasi matahari. Berikut ini merupakan hasil pengukuran rata-rata suhu dan radiasi matahari selama tiga kali percobaan.

Grafik rata-rata suhu ruang dan radiasi matahari menunjukan bahwa, terjadi kenaikan dan penuruan suhu dan radiasi matahari selama percobaan dilakukan. Rata-rata suhu ruang tertinggi yaitu sebesar $42,7^{\circ} \mathrm{C}$ yang terjadi pada percobaan pertama. Sedangkan rata-rata radiasi matahari tertinggi terjadi pada percobaan kedua yaitu sebesar 488,8 W/m². Dibandingkan dengan penelitian yang dilakukan oleh Mulyanef (2014) tentang pengolahan air laut menjadi air bersih dan garam dengan destilasi tenaga surya, diperoleh rata-rata radiasi matahari tertinggi sebesar $542 \mathrm{~W} / \mathrm{m}^{2}$ selama 4 hari percobaan. Hal itu disebabkan karena selama proses penyulingan berlangsung kondisi cuaca cerah dan tidak terjadi hujan. Sementara pada penelitian ini diperoleh nilai rata-rata radiasi matahari tertinggi sebesar $488,8 \mathrm{~W} / \mathrm{m}^{2}$, hal ini disebabkan karena selama proses penyulingan dilakukan terjadi hujan pada saat percobaan pertama dari tiga percobaan yang dilakukan.

\subsection{Efisiensi Energi}

Pada percobaan yang telah dilakukan, efisiensi energi terendah berada pada percobaan hari kedua dengan nilai efisiensi sebesar 16,49\% dan tertinggi pada percobaan ketiga dengan nilai 
sebesar 34,94\%. Nilai efisiensi dinyatakan pada Tabel 1. Pada Tabel 1 menjelaskan bahwa besaran energi yang dibutuhkan ketika air yang menguap sebanyak $814 \mathrm{ml}$ sebesar 5651,73 J sehingga besar energi yang dihasilkan jika dipersentasekan sebesar 34,94\%. Hal ini menunjukkan bahwa terdapat pengaruh terhadap kapasitas volume penguapan pada alat dan nilai efisiensi energi yang dihasilkan. Semakin banyak volume air yang menguap maka semakin besar efisiensi energi yang dihasilkan oleh alat kondensasi.

Pada penelitian yang telah dilakukan oleh (Dewantara, 2018) tentang Desalinasi Air Laut Berbasis Energi Surya Sebagai Alternatif Penyediaan Air Bersih memperoleh hasil nilai efisiensi sebesar 4,45\% dari sistem kerja alat yang diperoleh, sedangkan penelitian rancang bangun alat kondensasi model rumah kaca menunjukan hasil yang optimal karena memperoleh nilai efisiensi energi sebesar 34,94\%. Hal itu disebabkan karena cara pemanenan air tawar yang dilakukan secara manual dengan mengusap titik air ketika telah dalam kondisi jenuh dapat meminimalisir kehilangan air atau lose, dibandingkan dengan penelitian Dewantara (2018) jarak penampang kaca dengan bak air laut terlalu dekat sehingga menyebabkan banyaknya titik air yang jatuh kembali ke bak penampung air laut membuat kehilangan air atau lose tinggi.

\subsection{Efisiensi Hasil Penguapan}

Berdasarkan hasil penelitian yang telah dilakukan nilai efisiensi yang didapat dinyatakan pada Tabel 2. Dari Tabel 2 nilai tertinggi efisiensi hasil penguapan sebesar $24,85 \%$ dari total air yang menguap $503 \mathrm{ml}$. Efisiensi solar still (peralatan pemurnian air tenaga surya) masih rendah yaitu sekitar 30-40\%, karena adanya kehilangan panas laten untuk kondensasi uap air

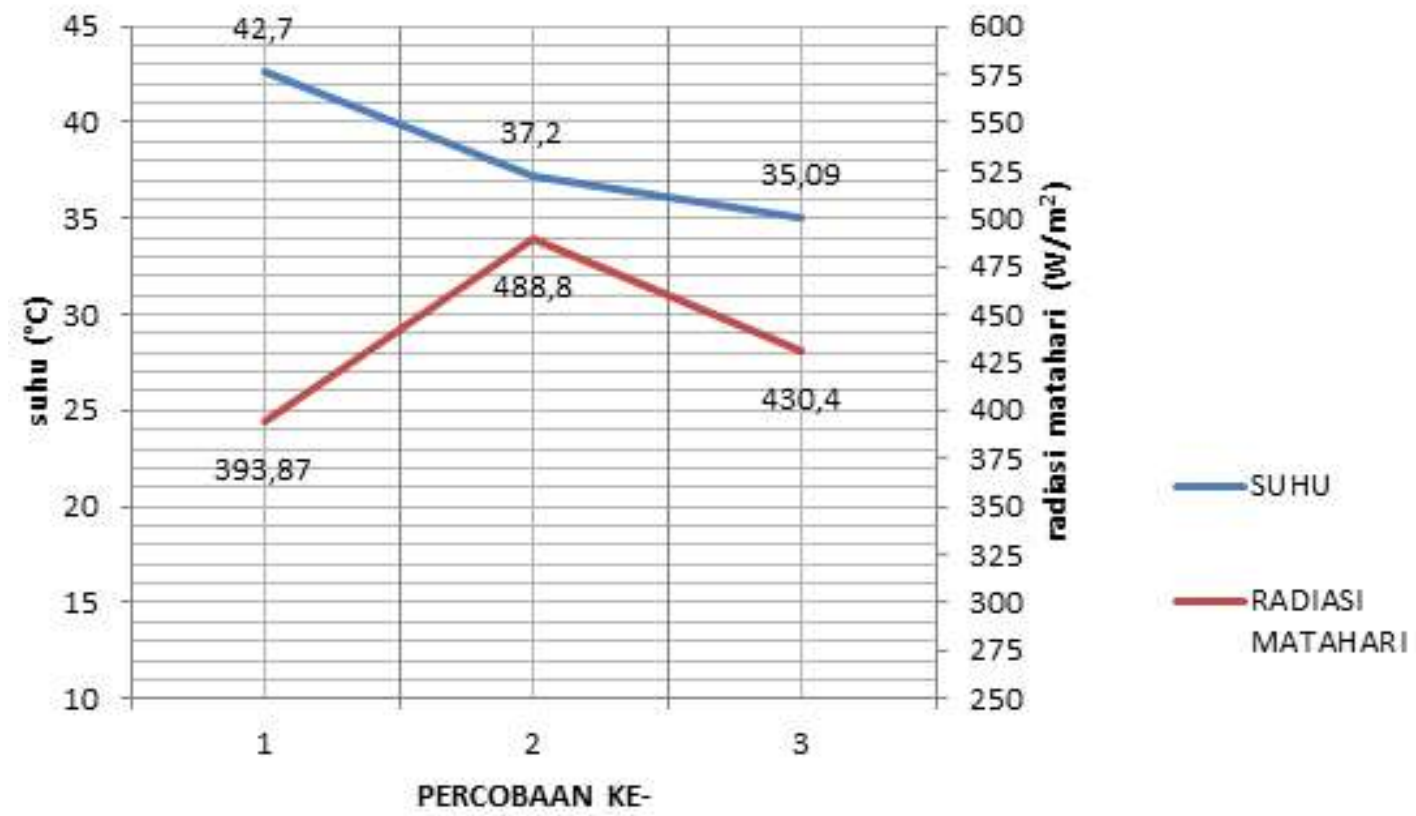

Gambar 4. Grafik Rata-rata Suhu Ruang dan Radiasi Matahari

Tabel 1. Efisiensi Energi Alat Kondensasi Uap Air Laut

\begin{tabular}{ccccc}
\hline Hari ke- & $\begin{array}{c}\text { Total Air yang } \\
\text { Menguap (ml) }\end{array}$ & $\begin{array}{c}\text { Energi untuk } \\
\text { Menguapkan Air } \\
\mathbf{Q}_{1} \text { (Joule) }\end{array}$ & $\begin{array}{c}\text { Energi yang } \\
\text { Menembus Alat } \mathbf{Q}_{2} \\
\text { (Joule) }\end{array}$ & $\begin{array}{c}\text { Efisiensi } \\
\text { (\%) }\end{array}$ \\
\hline 1 & 503 & 1262,84 & 5172,04 & $24,41 \%$ \\
2 & 421 & 1058,95 & 6418,60 & $16,49 \%$ \\
3 & 814 & 1976,83 & 5651,73 & $34,94 \%$ \\
\hline
\end{tabular}


Tabel 2. Efisiensi Hasil Penguapan Air Laut

\begin{tabular}{cccc}
\hline Hari ke - & $\begin{array}{c}\text { Hasil } \\
\text { (ml/harian) }\end{array}$ & $\begin{array}{c}\text { Total Penguapan } \\
\text { (ml/harian) }\end{array}$ & Nilai Efisiensi (\%) \\
\hline 1 & $125 \mathrm{ml}$ & $503 \mathrm{ml}$ & $24,85 \%$ \\
2 & $97,5 \mathrm{ml}$ & $421 \mathrm{ml}$ & $23,16 \%$ \\
3 & $152,5 \mathrm{ml}$ & $814 \mathrm{ml}$ & $18,73 \%$ \\
\hline
\end{tabular}

kelingkungan dan panas laten yang terbuang oleh kondensat (Delyanis dan Belessiotis, 2001).

Pemanen butiran air yang menenpel pada dinding plastik dilakukan dengan cara mengusap dengan wiper, tetapi tidak semua air dapat dipanen. Hal ini disebabkan oleh beberapa faktor, yaitu sebagian air tidak jatuh pada wadah penampung, dan sebangian air menempel pada wiper.Interval waktu pemanenan yang terlalu cepat juga menyebabkan kehilangan hasil panen air.Hal ini disebabkan karena banyaknya air yang terbawa oleh wiper sebagai pengusap.

Pada penelitian yang telah dilakukan oleh (Dewantara, 2018) memperoleh hasil permurnian air laut tertinggi sebesar $311,5 \mathrm{ml}$ air tawar dari 7 liter air laut yang diuapkan, jika dibandingkan dengan hasil yang diperoleh pada penelitian ini, maka rancang bangun alat kondensasi model rumah kaca menunjukan hasil yang lebih optimal karena mampu menghasilkan 152,5 ml air tawar dari 3 liter air laut yang diuapkan. Potensi pemurnian air laut dengan menggunakan pemanas energi matahari, dengan luas plastik untuk masuk cahaya matahari 3,2 $\mathrm{m}^{2}$ didapat $152,5 \mathrm{ml}$ selama penjemuran 10 jam. Besar air murni yang dapat dipanen sangat tergantung pada, besar energy Radiasi matahari yang sampai ke alat penguapan, luasnya dinding plastik yang dapat memasukan radiasi matahari kedalam ruang penguapan air laut, teknik pemanen air dan tingkat ke kedap ruang penguapan.

\section{KESIMPULAN DAN SARAN}

\subsection{Kesimpulan}

Potensi alat pemurnian air laut dalam bentuk kotak dengan pemanasan menggunakan prinsip efek rumah kaca, luas dinding plastik untuk masuknya cahaya matahari sebesar $3,2 \mathrm{~m}^{2}$ dan penjemuran selama10 jam adalah $152,5 \mathrm{ml}$. Alat pemurnian air laut model rumah kaca ini memiliki dimensi panjang $80 \mathrm{~cm}$, lebar $80 \mathrm{~cm}$, dan tinggi $125 \mathrm{~cm}$. Alat ini dapat menyuling air laut menjadi air murni dengan memanfaatkan sumber tenaga matahari sebagai pemanas alami. Alat ini memiliki nilai rata-rata efisiensi energi penguapan air laut berkisar 16,49 \%-34,94\%. Kinerja alat ini dipengaruhi oleh keadaan radiasi matahari dan suhu didalam kotak, semakin tinggi radiasi matahari dan suhu maka semakin banyak uap air terjadi dan semakin uap air terkondensasi pada dinding plastik.

\subsection{Saran}

Berdasarkan penelitian yang telah dilakukan terdapat beberapa hal yang perlu dirujuk menjadi saran penelitian selanjutnya yaitu dengan membuat instalasi saluran penampung air secara otomatis agar pada saat pemanenan air murni dapat ditampung secara maksimal.

\section{DAFTAR PUSTAKA}

Astawa, K., 2008. Pengaruh penggunaan pipa kondensat sebagai heat recorvery pada basin type solar still terhadap efisiensi. Jurnal Ilmiah Teknik Mesin Cakram, 2(1): 34-41.

Dewantara, I., Suyitno, B.M., dan Lesmana, I.G.E. 2018. Desalinasi air laut berbasis energi surya sebagai alternatif penyediaan air bersih. Jurnal Teknik Mesin, 7(1): 1-4.

Deng, R., Xie, L., Lin, H., Liu, J., Han, W. 2010. Integration of thermal energy and seawater desalination. Energy, 36 : 43684374.

Delyanis, E dan Belessiotis V., 2001. Solar energy and desalination, advances in solar energy, an annual review of research and 
depolepment. D.Y. Goswami, Ed, Vol 14, Amerecan Solar Energy Society, Boulder Clorado

Effendi, S.M., Arifin, K.M., Hasbi, M. 2012.Pengaruhu penggunan preheater pada basin type solar still dengan tipe kaca penutup miring pada effisiensi. Spektrum Industri 10 (2): 121 - 133.

Lanto, M.S. dan Iswadi. 2016. Rancang bangun alat pemurni air laut menjadi air minum menggunakan sistem piramida air (green house effect) bagi masyarakat pulau dan pesisir di kota makassar. Jurnal Sains dan Pendidikan Fisika, 12(3): 300 - 310.

Mulyanef, Burmawi, dan Muslimin. K. 2014. Pengolahan air laut menjadi air bersih dan garam dengan destilasi tenaga surya. Jurnal Teknologi Industri, 4(1) : 25-29.

Zulkarnain, I., Raharjo, I., Istanto, K, 2018. Rancang bangun alat pemurnian air laut tenaga surya dengan kolektor panas cermin cekung.Jurnal Teknik Lingkungan, $4(2): 1-10$.

Priyono, Amin, C. dan Jauhari, A., 2016. Strategi adaptasi masyarakat terhadap bencana kekeringan di kawasan karst. Prosiding Seminar Nasional Geografi, Upaya Pengurangan Risiko Bencana Alam, Semarang 2016.

Yuan, G., Wang, Z., Li, H., dan Li, X. 2011. Experimental study of a solar desalination system based on humidificationdehumidification process. Desalination, 277: 92-98.

Yilmaz, I. H. dan Soylemez, M. S.2012. Design and computer simulation on multi-effect evaporation seawater desalination system using hybrid renewable energy sources in turkey. Desalination, 291 : 23-40. 